\title{
Leisure Skills
}

National Cancer Institute

\section{Source}

National Cancer Institute. Leisure Skills. NCI Thesaurus. Code C121195.

An assessment of the Adaptive Behavior Assessment System, where leisure skills such as planning recreational activities, playing with others, and following rules of games are evaluated. 